\title{
CHANGE OF PARAMETERS IN PROOXIDANT-ANTIOXIDANT BILE SYSTEM IN PATIENTS WITH THE OBSTRUCTION OF BILE-EXCRETING DUCTS
}

\author{
Bykov M. I., Basov A. A.
}

Kuban State Medical University, Krasnodar, Russian Federation

\section{ИЗМЕНЕНИЕ ПОКАЗАТЕАЕЙ ПРООКСИААНТНО-АНТИОКСИААНТНОЙ СИСТЕМЫ В ЖЕАЧИ У ПАЦИЕНТОВ С АИСТААЬНОЙ ОБСТРУКЦИЕЙ ЖЕАЧЕВЫВОАЯЩИХ ПРОТОКОВ}

\author{
М. И. Быков, А. А. Басов \\ Кубанский госуАарственный меАицинский университет, КрасноАар, \\ Российская ФеАерация
}

The paper found that among the patients with choledocholithiasis and malignant neoplasms of biliopancreatoduodenalis area in the development of cholangitis it is observed a significant reduction in the capacity of the antioxidant system at the local level (in bile) by $78.3 \%$ and $72.9 \%$, respectively. The paper showed that for the evaluation of the degree of decompensation in antiradical protection in biliary obstruction and inflammatory complications it is necessary to determine as additional indicators in bile the state level of the enzymes in the antioxidant system: the activity of catalase and superoxidedismutase that could improve the diagnosis in these pathological conditions and in addition would allow to appoint timely corrective actions and monitor the effectiveness of the therapy. The study showed that the catalase activity increased in the bile in patients with choledocholithiasis as compared to control values by 1.7 times in the absence of inflammatory complications and by 5.1 times - under cholangitis; in patients with malignant neoplasms of biliopancreatoduodenalis area its activity decreased by $49.4 \%$ while decreasing the area of maximum chemoluminescence by $42.2 \%$ and $72.5 \%$ respectively, whereas in the development of cholangitis the catalase activity increased by 4.5 times. In this case the increase in superoxidedismutase activity in all study groups was even more significant, indicating the adaptive changes, as well as the emerging imbalance in the enzymes of the 1st and 2nd line of the antioxidant system (mainly due to dismutase activity), which might be accompanied by a decrease in local nonspecific resistance, especially in inflammatory complications in patients with the studied nosologies.

Key words: bile, chemiluminescence, cholangitis, antioxidant activity, catalase

У пациентов с холедохолитиазом и со злокачественными новообразованиями органов билиопанкреатодуоденальной зоны при развитии холангита наблюдается достоверное снижение потенциала антиоксидантной системы в желчи на 78,3 и 72,9\% соответственно. Для оценки степени нарушения антирадикальной защиты при обструкции желчевыводящих протоков и воспалении необходимо определять состояние ферментного звена антиоксидантной системы в желчи: активность каталазы, супероксиддисмутазы, что позволит контролировать эффективность проводимой терапии. Активность каталазы в желчи повышалась у пациентов с холедохолитиазом в сравнении с контрольными значениями в 1,7 раза при отсутствии гнойно-воспалительных осложнений и в 5,1 раза - при развитии холангита. У больных со злокачественными новообразованиями органов билиопанкреатодуоденальной зоны активность снижалась на 49,4\% с одновременным понижением максимума и площади хемилюминесценции на 42,2 и 72,5\% соответственно, тогда как при развитии холангита активность каталазы возрастала в 4,5 раза. При этом рост активности супероксиддисмутазы во всех обследованных группах был еще более существенным, что указывает на адаптационные изменения и формирование дисбаланса в работе ферментов 1-й и 2-й линий антиоксидантной системы (преимущественно за счет дисмутазной активности), который может сопровождаться снижением локальной неспецифической резистентности.

Ключевые слова: желчь, хемилюминесценция, холангит, антиоксидантная активность, каталаза 
$\mathrm{T}$ he problem of restoration of adequate passage of bile in patients with the obstruction of bile-excreting ducts still remains quite urgent in surgical practice [1, 17]. Differential diagnostics of the causes of the biliary tract obstruction is difficult because of the similarity of their clinical manifestations and changes in laboratory data. Late diagnosis and wrong treatment algorithm lead to the development of acute purulent cholangitis, which aggravates the clinical course of the underlying disease and in combination with obstructive jaundice contributes to the progression of liver failure and the increased mortality due to a significant increase in postoperative complications, especially in elderly patients. Hypertension of the bile ducts resulting from up the obstruction and the absence of bile in the intestine lead to the development of inflammatory changes of the biliary tract while the inflow of bile elements into the blood causes intoxication and development of severe morphological and functional disorders of the liver parenchyma, kidney and other organs and systems [10,12]. The absence of bile in small intestine does not allow restoring the balance of its microflora, interrupting toxins activation and reducing the symptoms of intoxication, that, inter alia, determines the severity of the patients' condition [9].

Alongside the perfection of non-invasive diagnostic methods of biliary pathology there is the technological progress in the performance of chrysolampis endoscopic interventions [19], which reduces the number of postoperative complications significantly [18]. Despite the progress achieved in the diagnosis and treatment biliary obstruction (primarily due to the introduction of modern minimally invasive technologies into clinical practice of medical institutions) lots of problems of modern diagnostics and rational treatment policy for these patients remain unsolved.

Taking into consideration all the foregoing, the study of the state of nonspecific protection at the local level, especially the local indicators of prooxidant-antioxidant protection for the improvement of the effectiveness of corrective actions is required. Taking into account the multilevel organization of the antioxidant system, the complex regulation of peroxidation processes in the body as well as the on-going search for new ways of oxidative metabolism disorders treatment $[13,15]$, for an objective assessment of protective systems with biliary obstruction it is required to develop an algorithm of laboratory diagnostics, which will also allow dynamic monitoring the effectiveness of the undertaken corrective actions. One of the problems of modern laboratory diagnostics in the surgical treatment of patients with obstruction of the bile ducts and phenomena cholangitis is searching for biological material that allows not only diagnosing the prooxidant-antioxidant balance disorders at the local level, but also systematic monitoring the state of the antioxidant system and the level of free radical oxidation directly in the biliary tract. Currently the scientific literature does not yet have enough information as for the possible use of bile for the assessment of the level of violations of antiradical defense in the body and prediction of the adverse outcomes [2]. So, the development of new algorithms for laboratory diagnosis is considered necessary.

Therefore the aim of this work is to study the state of prooxidant-antioxidant system in the bile in the patients with obstruction of bile-excreting ducts (choledocholithiasis, malignant neoplasms of biliopancreatoduodenalis area), including the development of inflammatory complications.

Material and Methods. Examination of patients and biopsy specimens were performed in the endoscopy department № 2 of state budgetary institution of health care "Scientific Research Institute - Regional Clinic № 1 named after Professor S. V. Ochapovsky" (Krasnodar). The bile of the patients with the obstruction of bile ducts was taken as the research material, the bile sampling was carried out by endoscopic manipulations using endoscopic sterile catheters. Control Group 1 consisted of 38 patients with no evidence of choledocholithiasis and malignant neoplasms of biliopancreatoduodenalis area, comparable in age and sex with other groups examined. Group $2(n=19)$ consisted of patients with malignant neoplasms of biliopancreatoduodenalis area without clinical and laboratory manifestations of cholangitis; Group $3(n=21)$ consisted of patients with malignant neoplasms of biliopancreatoduodenalis area, aggravated by acute cholangitis; Group $4(n=42)$ consisted of patients with choledocholithiasis without clinical and laboratory manifestations of cholangitis; Group $5 \quad(n=37)$ consisted of patients with choledocholithiasis, aggravated by acute cholangitis. Patients with grave disorders of the esophagus, the stomach and the duodenumaggravated by the obstruction were excluded from the investigation program because their poor general health made safe endoscopy of the gastrointestinal tract impossible.

Bile antioxygenic activity was determined by the amperometric technique using «Yauza-01AAA» analyzer [20]. Current flow originating from oxidation on the surface of the standard electrode (ascorbic acid in concentration $0.1-0.8 \mathrm{mg} / \mathrm{l}$ ) was measured. On the basis of these data metering diagram was made. The present investigation was carried out under the support of the Ministry of Health Care of the Russian Federation (28.01.2015, part 1, chapter 1) «Carrying out the Applied Scientific Researches including Pre-clinical Trial of the Medicinal Agents and Clinical Trials of Drugs.»

Superoxide dismutase, catalase activity as the index of enzymatic chain of the radical defense was studied. Colorimetric method based on the ability of hydrogen peroxide combined with molybdenum 
salts to give a stable dyeing complex was used to determine the bile catalase activity [7]. Catalase activity was assessed according to the amount of hydrogen peroxide remained in the reactionary system after the catalase reaction, the measuring unit being mct/l of bile. Superoxide dismutase activity in bile was established by the method based on the superoxide dismutase ability to inhibit kverzetin self-oxidation reaction due to superoxide onion radical dismutation produced in the process of kverzetin oxidation in the presence of $\mathrm{N}, \mathrm{N}$, $\mathrm{N}_{1}, \mathrm{~N}_{1}$ - tetramethyllenediamine under oxybiotic conditions [8], the measuring units being unit $/ \mathrm{ml}$. When assessing the free radical oxidation intensity in blood plasma the method of lumenol dependent $\mathrm{H}_{2} \mathrm{O}_{2}$ induced chemo luminescence was used. Maximal chemi luminescence flash (MCLF) and the chemi luminescence area (CLA) were measured by LT-01 chemiluminescence analyzer according to the technique [3] and were expressed in relative units and unit surface area respectively.

Statistical analysis was performed according to the methods used in variation statistics and free softwear R (R Development Core Team, 2008), the difference $p<0.05$ was considered reliable. Mean values as well as standard errors in average values were calculated. Non-parametric U-test by MannWhitney was used to assess the differences in average values among the groups (for independent groups).

Results and Discussion. The study has proved that catalase activity in group 2 was reduced as compared to control values by $49.4 \%$ and was accompanied by the decrease in the maximum flash chemiluminescence and the size of chemiluminescence at $42.2 \%$ and $72.5 \%$ respectively while in group 3 catalase activity was increased by 4.5 times. It indicates significantly increased necessity at the local level to neutralize the peroxide compounds under the developing the inflammatory process. In patients with choledocholithiasis catalase activity increased by $71.1 \%$ while under the development of cholangitis catalase activity of bile was 5.1 times as high and similar indicators in group 4 were 2.9 times as high $(p<0.05)$. The activity of superoxide dismutase changed even more significantly : in group 2 it was 7.9 times as high as compared with control values, and in group 3 its activity grew up at 13.1 times as compared to control values and it was $66.0 \%$ as high $(p<0.05)$ as in group 2 (Table); in group 4 the activity of superoxide dismutase increased by 9.1 times, in group 5 by 16.3 times $(59.8 \%$ as high as compared with the values in group $4, p<0.05)$. These data indicate the marked formation of superoxide anion- radical under biliary ducts obstruction as well as the disbalance in the work of the enzymes of the 1st and 2nd lines of the antioxidant system (mainly due to dismutase activity). The disbalance may be accompanied by the decrease in local nonspecific resistance especially in patients with choledocholithiasis and neoplasms of biliopankreaticduodenal area under inflammatory processes. According to worldwide and Russian statistics these processes are considered to be one of the main causes of disability and mortality $[6,11]$. As a rule, inflammatory reactions in the biliary ducts are attributed to two predisposing anatomical and physiological conditions: bile stasis and eventual local infections. Specific role the enzyme link of the antioxidant system plays when protecting the body in inflammatory processes is attributed to the neutralization of free radicals and reactive molecules the formation of which is greatly increased under condition of oxidative stress [14]. Irrelevant functioning of antioxidant enzymes may lead to progressive pathological process and increase the frequency of unfavorable outcomes in the postoperative period.

The state of the prooxidant-antioxidant gall system in patients with the obstruction of the bile-excreting ducts $(\mathbf{M} \pm \mathbf{m})$

\begin{tabular}{|l|c|c|c|c|c|}
\hline \multicolumn{1}{|c|}{ Index } & Group 1 & Group 2 & Group 3 & Group 4 & Group 5 \\
\hline Antioxidant & 741.63 & 301.86 & 200.78 & 793.64 & 160.67 \\
activity, mg/l & \pm 44.49 & $\pm 16.5^{*}$ & $\pm 19.4^{*} \#$ & \pm 21.58 & $\pm 26.01^{* \wedge}$ \\
\hline MFChL, c.u. & 1.92 & 1.11 & 3.96 & 2.35 & 3.14 \\
& \pm 0.84 & \pm 0.06 & \pm 0.23 & \pm 1.11 & \pm 0.35 \\
\hline ChLA, a.u. & 171.75 & 47.30 & 389.31 & 194.91 & 233.73 \\
& \pm 7.30 & $\pm 8.76 *$ & $\pm 27.3^{*} \#$ & \pm 12.96 & \pm 13.97 \\
\hline SOD, u/ml & 2.76 & 21.84 & 36.27 & 25.05 & 40.04 \\
& \pm 0.06 & $\pm 0.61^{*}$ & $\pm 0.58^{*} \#$ & $\pm 0.74^{*}$ & $\pm 0.99^{* \wedge}$ \\
\hline catalase, & 8.99 & 4.56 & 40.87 & 15.42 & 45.63 \\
mAb/l & \pm 0.32 & $\pm 0.15^{*}$ & $\pm 0.95^{*} \#$ & $\pm 0.39^{*}$ & $\pm 1.80^{* \wedge}$ \\
\hline
\end{tabular}

$*-p<0.05$ in comparison with indices of group 1 (the control group), $\#-p<0.05$ in comparison with indices of group 2 , $\wedge_{-p}<0.05$ in comparison with indices of group 4 .

Described pathological and biochemical disorders led to the reduction of antioxidant activity of bile to $59.3 \%$ in group 2 and more expressed decrease in group 3 (to 72.9\%). Choledocholithiasis, aggravated by cholangitis, lowering antioxidant activity of bile was most significant (to $78.3 \%, p<0.05$ ) while in group 4 no reliable violations of the total antioxidant activity of bile were marked thanks to adaptive changes in antiradical defence enzyme activity. The above mentioned points to a deeper prooxidantantioxidant system disbalance, aggravating the condition of patients with both malignant neoplasms of the biliopankreaticduodenal area and choledocholithiasis under acute cholangitis. Alongside the decrease in the antioxidant capacity of bile the intensity of free radicals often increases, especially in groups 3 and 5 (to $126.7 \%$ and $36.1 \%$ respectively (Table), that proves the severity of the inflammatory process in the biliary tracts and increases the risk of suppurative and cicatrical complications under the condition of enhanced oxidative modification of biomolecules. The modification of amino acids in proteins results in the violation of not only primary but also secondary and tertiary structure that leads to aggregation or 
fragmentation of protein molecules according to the amino acid composition. Therefore, the increase in the catalase and superoxide dismutase bile activity in the examined groups of patients proves compensatory-adaptive reactions of nonspecific defense system and is accompanied by adaptive disorders in case of inflammatory complications.

Systemic injections of antibacterial drugs for the treatment of acute cholangitis in patients with mechanical jaundice have proved to be ineffective. The results received reflect local disorders in the system of nonspecific bile defense and explain why many scientists note the efficacy of introductive influences such as cholecorbtion, ozone therapy, electrophoresis, laser irradiation, etc. for comprehensive treatment of cholangitis. It is due to the fact that in cholangitis the disorders of the local system of nonspecific defense are expressed clearly and modified therapy with antibacterial, antiviral, antiinflammatory and immunomodulating action are required to intensify microchemodynamics thus correcting the damages of peroxide biomolecule oxidation, to increase the oxidant defense as well as detoxication and to support the energy homeostasis of the bile ducts. Low-invasive decompression of bile ducts is the most effective and safe therapy in such cases [4, 5, 16]. It significantly decreases intoxication, prevents the development of the pyoseptic complications and reduces the incidence of poliorganic insufficiency.

The experiments have proved that the determination of low molecular and enzyme components of the antiradical defense is of great diagnostic value for the assessment of antioxidant system disbalance as it definitely shows the severity of local damages both in patients with tumors of the biliopancreatduodenal organs and in patients with

\section{References}

1. Agaev B. A., Agaev R. M., Gasymov R. S. Hirurgija. Zhurnal im. N.I. Pirogova. 2011;1:18-22.

2. Arutunyan A. V., Dubinina E. E., Zibina N. N. Metody ocenki svobodnoradikal'nogo okislenija i antioksidantnoj sistemy organizma: metod. Rekomendacii. - SPb.: Foliant, 2000. 104 pp.

3. Basov A. A., Pavlyuchenko I. I., Plaskin A. M., Fedosov S. R. Vestnik novyh medicinskih tehnologij. 2003;10(4):67-68.

4. Gusev A. V., Balagurov B. A., Borovkov I. N., Konkov O. I., Martinsh Ch. T., Pokrovskiy E. Zh., Raskin A. V., Stankevich A. M. Vestnik novyh medicinskih tehnologij. 2008;15(4):97-98.

5. Zavrazhnov A. A., Popov A. U., Petrovskiy A. N., Litshenko A. N., Bykov M. I., Popov P. V., Litshinin V. Y. Zhurnal im. N. V. Sklifosovskogo. Neotlozhnaja medicinskaja pomosh'. 2012;2:54-58.

6. Kazantzeva M. V., Teslenko L. G., Tzokur I. V., Bondareva I. S. Zlokachestvennye novoobrazovanija v Krasnodarskom krae (2009-2013 gody). Sostojanie onkologicheskoj pomoshhi naseleniju. Krasnodar: Publishing House «Fleur», 2014. 280 pp.

7. Korolyuk M. A., Ivanov L. I., Mayorova I. G., Tokarev V. P. Laboratornoe delo. 1988;1:16-19.

8. Kostyuk V. A., Potapovitch A. I., Kovaleva Zh. I. Voprosy medicinskoj himii. 1990; 2:88-91.

9. Kulezneva U. V., Israilov R. E., Kapustin V. I. Vestnik Nacional'nogo mediko-hirurgicheskogo centra im. N. I. Pirogova. 2010;5(2):24-28. choledocholithiasis including the patients with inflammatory complications.

Conclusions. It is necessary to register that the resistance of the body to oxidization damage is determined by the interactive work of all mechanisms protecting the organism from free radicals. Judging by the results, patients with neoplasms in biliapancreasduodenum zone and patients with choledocholithiasis have expressed disunity in antiradical defence ferments functioning that is more explicit under cholangitis and results in the reduction of low-molecular link antioxygen potential of antiradical defence in bile. The experiments have proved that it is the study of enzymatic and non-enzymatic indicators of antiradical defence in bile that makes it possible to assess the exact nonspecific defence potential of the body, that can be used in diagnostic algorithm for diagnosing oxydative stress in biliary ducts by means of minimally invasive methods and for antioxidant system disfunction specification in holystaze. It should be noted that the examined patients had stronger antioxidant defence reserves alongside the increased superoxidedesmutase activity that allow levelling free radicals damaging influence (superoxidative anion-radical, first and foremost) on the bile-excreting ducts mucous membrane at some stage. Further improvement of GMP for endoscopic trans-papillary procedures with concurrent biochemical indices determination (in bile) at the local level (catalase and superoxide dismutase activity including ) is considered to be a lot more effective in assessing the state of health of the patients with bile outflow mechanical disorders as well as in the correction of the local system nonspecific defence disfunction, including complex antioxidant therapy.

10. Labiya A. I., Bagmet N. N., Ratnikova N. P., Skipenko O. G. Hirurgija. Zhurnal im. N. I. Pirogova. 2007;6:26-29.

11. Pautkin Yu. F., Klimov A. E. Mehanicheskaja neprohodimost' zhelchnyh putej (mehanicheskaja zheltuha). M.: Profile. 2C., 2010. 224 pp.

12. Rybachkov V. V., Dryazhenkov I. G., Kabanov E. N. Annaly hirurgicheskoj gepatologii. 2009;14(2):28-32.

13. Basov A. A., Bykov I. M. Voprosy Pitaniia. 2013;82(3):7780.

14. Basov A. A., Baryshev M. G., Dzhimak S. S., Bykov I. M., Sepiashvili R. I., Pavlyuchenko I. I. Fiziolohichnyi zhurnal. 2013;59(6):50-57.

15. Bykov I. M., Basov A. A., Bykov M. I., Khanferyan R. A. Voprosy Pitaniia. 2014;83(4):75-81.

16. Costamagna G., Pandolfi M. J. Clin. Gastroenterol. 2004;38:59-67.

17. Cotton P.B. Endoscopic and Related Abstracts of the NIH State-of-the-Science Conference on Endoscopic Retrograde Cholangiopancreatography (ERCP) for Diagnosis and Therapy. Bethesda, Maryland. - William H. Natcher Conference Center National Institutes of Health, 2002. P. 81-90.

18. Kalakhanova B. Kh., Chechenin G. M., Lebedev S. S., Barinov Y. V., Seregin A. A., Melkonyan G. G., Mumladze R. B. STM. 2014;6(4):97-101.

19. Ringold D. A., Jonnalagadda S. Tech. Gastrointest. Endosc. 2007;9(2):90-103.

20. Yashin A. Y. Russian Journal of General Chemistry. 2008;78(12):2566-2571. 


\title{
About authors:
}

Bykov Mikhail Ilyitch, Associate professor of the Department of Surgery N 1, Kuban State Medical University; tel.: +789183596296; e-mail: bikov_mi@mail.ru

Basov Alexander Alexandrovitch, Associate professor of the Department of Basic and Clinical Biochemistry, Kuban State Medical University; tel.: +79183551302; e-mail: son_sunytch@mail.ru

\section{ENHANCED RECOVERY AFTER SURGERY IN PATIENTS WITH BODY MASS INDEX OVER 50}

\author{
Khatsiev B. B., Uzdenov N. A., Kuzminov A. N.
}

Stavropol State Medical University, Stavropol, Russian Federation

\section{УСКОРЕННАЯ РЕАБИАИТАЦИЯ ПОСАЕ ХИРУРГИЧЕСКИХ ВМЕШАТЕАЬСТВ У ПАЦИЕНТОВ С ИНАЕКСОМ MACСЫ TEАA БOАEE 50}

\author{
Б. Б. Хациев, Н. А. УзАенов, А. Н. Кузьминов \\ Ставропольский госуАарственный меАицинский университет, \\ Ставрополь, Российская ФеАерация
}

50 patients were included in the study. They were divided according to body mass index (BMI) into two groups: 15 patients with BMI over 50 and 35 patients with BMI below 50 . Sleeve gastrectomy for morbid obesity was performed in all patients. Mean operative time was $90 \pm 33$ minutes in low BMI group and $124 \pm 36$ minutes in high BMI group $(p<0.01)$. Postoperative management did not differ between groups.

Complications occurred in $2(13.3 \%)$ patients with $\mathrm{BMI}>50$ and in $4(11.4 \%)$ patients with $\mathrm{BMI}<50$, $\mathrm{p}>0.05$. Mortality was zero in both groups. Mean postoperative in-hospital time was $2.2 \pm 0.9$ ( 1 to 4 ) days in high BMI group and 3.0 \pm 2.0 ( 1 to 9 ) days in low BMI group, $p>0.05$.

Results of enhanced recovery methods did not revealed any significant differences between high and low BMI groups. We think that results could be implemented in bariatric surgery; however, enhanced recovery for super-obese patients in other non-bariatric procedures needs further investigation.

Key words: bariatric surgery, fast track, enhanced recovery

Обследовано 50 пациентов, разделенных в соответствии с индексом массы тела (ИМТ) на две группы: 15 пациентов с ИМТ свыше 50 и 35 пациентов с ИМТ менее 50. Всем больным выполнялась лапароскопическая продольная резекция желудка. Средняя длительность операции (включая время симультанной операции) составила $90 \pm 33$ минут в контрольной группе и 124 \pm 36 минут в основной $(p<0,01)$. Пациенты получали лечение по одинаковой схеме ускоренной реабилитации.

Осложнения возникли у $2(13,3 \%)$ - с ИМТ $>50$ и у $4(11,4 \%)$ пациентов с ИМТ $<50$, p $>0,05$. Летальных случаев не было ни в одной из групп. Длительность пребывания пациентов в стационаре

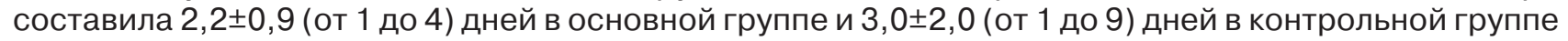
$(p>0,05)$.

Результаты применения протоколов ускоренной реабилитации не выявили статистически значимых различий между группами больных с ИМТ ниже и выше 50. Полагаем, что результаты применимы к пациентам со сверхожирением в бариатрической хирургии, однако в других областях хирургии требуются дальнейшие исследования.

Ключевые слова: бариатрическая хирургия, fast track, ускоренная реабилитаци 